УДК:624.04, 629.5.015.4, 629.5.035.8

${ }^{1}$ О. І. Урсолов, канд. техн. наук, ${ }^{2} Ю$. А. Батрак

\title{
МАТРИЦЯ ЖОРСТКОСТІ \\ СТРИЖНЕВОГО СКІНЧЕННОГО ЕЛЕМЕНТА НА ПРУЖНІЙ ОСНОВІ 3 НЕЛІНІЙНОЮ ЖОРСТКІСТЮ УЗДОВЖ ЕЛЕМЕНТА
}

Розглянута задача моделювання підшипника суднового валопровода 3 неметалевим вкладишем як пружної основи методом скінченних елементів. Виконано аналіз існуючих матриць жорсткості стрижневих скінченних елементів на пружній основі. Розроблено матрицю жорсткості елемента на пружній основі Вінклеровського типу 3 параболічним законом зміни коефіцієнта жорсткості за довжиною елемента. Показана ефективність розробленої матриці порівняно з матрицями, отриманими 3 використанням постійного і лінійного розподілу жорсткості. Подані рекомендації щодо вибору кількості елементів, необхідних для адекватного моделювання неметалевих вкладишів підшипників суднового валопровода.

Ключові слова: підшипник, пружна основа, метод скінченних елементів, матриця жорсткості,стрижневий скінченний елемент.

Вступ. Точність та якість розрахунків суднового валопровода впливає на термін безаварійної експлуатації судна, на рівень та інтенсивність вібрації кормової частини судна.

Судновий валопровід $€$ багатопрогонною балкою ступінчастозмінного кругового перерізу, основним методом розрахунку згину якої на сьогоднішній день $є$ метод скінченних елементів (MCE) в його стрижневій реалізації, наприклад [6, 13].

Основною проблемою у задачі розрахунку форми згину суднового валопровода за допомогою МСE $€$ форомулювання граничних умов на підшипниках. Валопровід спирається на підшипники ковзання, довжина вкладишів яких відноситься до діаметру вала у межах від 1:1 для підшипників проміжних валів та до 4:1 для кормових дейдвудних підшипників або підшипників кронштейнів. Така видовженість кормових підшипників викликана вимогами класифікаційних товариств [14].

Вкладиші підшипників проміжних валів, видовженість яких не перевищує 1:1, змащуються оливою i, як правило, виготовлені з білого металу (бабіту). Їх у розрахунках валопроводів доволі точно можна предсталяти жорсткою вузловою опорою. Інша справа підшипники дейдвудів або кронштейнів. У зв'язку зі значним забрудненням акваторії світового океану мастилом, що витікає через ущільнення дейдвудного пристрою суден, відбувається повернення до їх змащення водою [15]. 3 огляду на це, у якості матеріалу вкладишів використовується гума й різноманітні

() О. І. Урсолов, Ю. А. Батрак, 2019 
синтетичні матеріали, вимоги до умов роботи яких значно жорсткіші ніж у випадку металевих підшипників. Формулювання граничних умов для таких підшипників й методи їх розрахунку є значно складнішими.

3 загальної точки зору, судновий неметалевий підшипник для валопровода $€$ односторонньою нелінійною пружною основою з невизначеною наперед зоною контакту. Тобто функцію жорсткості пружної основи підшипника неможливо заздалегідь описати аналітично. Матеріали вкладишів таких підшипників мають низький модуль пружності й коефріцієнт Пуассона близький до граничного значення 0,5. Оскільки коефіцієнт жорсткості пружної основи підшипника валопровода залежить від величини деформації вала й вкладиша, це спричиняє значну нелінійність математичної моделі. Такого роду нелінійності можна подолати лише методом послідовних наближень, втім це не $є$ предметом даної роботи. Дана робота присвячена створенню бази для таких розрахунків урахуванню нелінійного розподілу коефіцієнта жорсткості пружної основи вздовж елемента.

Аналіз попередніх публікацій. Існують два підходи до урахування наявності пружної основи у межах MCE: моделювання за допомогою жорсткостей, сконцентрованих у вузлах (node-spring simulation method), i використання спеціальних скінченних елементів (наприклад, Winklerbased element). У [11] виконано порівняння цих двох підходів з точним теоретичним розв'зком і показано, що через вузлову ідеалізацію перший підхід втрачає точність моделювання природи неперервної пружної основи. Другий підхід, зберігаючи природу пружної основи, для досягнення заданої точності потребує набагато менше скінчених елементів [9]. Це дуже важливо з точки зору швидкості виконання ітераційного розв'язання нелінійних задач. 3 огляду на це, у роботі обрано другий підхід.

Матриці жорсткості скінченних елементів на пружній основі Вінклера, що використовують апроксимацію лінії згину балки уздовж кубічним поліномом, а жорсткість пружної основи за довжиною елемента $є$ постійною, наведені у $[1,2]$. Це $€$ найпростіші та найбільш поширені на практиці матриці жорсткості. Матриця жорсткості, розроблена у [3, 10], базується на розв'язку диференційного рівняння згину балки на пружній основі Вінклера через функції О. М. Крилова. Вона має більш громіздку форму, іï побудова займатиме більше розрахункового часу, але математично вона $€$ більш точною, ніж названа вище. В [1] розроблено матрицю жорсткості скінченного елементу на нелінійно-пружній основі Вінклеровського типу. В отриманій матриці врахована характеристика нелінійності жорсткості основи, специфічна для задачі, що розв'язувалися автором, тому ця матриця не $є$ універсальною.

Найбільш прийнятний підхід до створення матриці жорсткості елемента на пружній основі використано в [9]. Згин елемента апроксимовано поліномом п'ятого степеня, а закон зміни жорсткості пружної основи апроксимовано лінійно. Але отримана матриця жорсткості $€$ громіздкою та не зручною для використання у випадку просторового згину, який $є$ характерним для валопровода судна. Окрім того, лінійний закон жорст- 
кості пружної основи вздовж елемента не відповідає властивостям деформування вкладиша неметалевого підшипника.

Існує також низка інших матриць жорсткості скінченних елементів на пружній основі $[8,12,16,17]$ з урахуванням зсуву у пружній основі, поздовжніх сил зсуву по лінії контакту та взаємодії означених фракторів. Однак ці моделі не відповідають умовам роботи вкладиша підшипника ковзання.

Постановка проблеми та цілі роботи. Матриця жорсткості скінченного елементу, що лежить на пружній основі $є$ сумою

$$
[K]=\left[K_{c e}\right]+\left[K_{n o}\right],
$$

де $\left[K_{c e}\right]$ - звичайна матриця жорсткості скінченного елемента вала [6] або [7]; $\left[K_{n o}\right]$ - матриця елементів жорсткості пружної основи елемента, що є власно предметом даної статті.

Слід зазначити, що у фрормулі (1) не враховується локальне деформування вала. При використанні у якості матеріалу вкладиша полімерів чи гуми можна вважати вал недеформівним, оскільки модуль пружності цих матеріалів на порядки менший за модуль сталі, з якої виготовляють вали.

Оскільки вал у межах довжини вкладиша згинається і практично ніколи не буває паралельним до осі підшипника, вкладиш за довжиною дефрормується нерівномірно. Принагідно зауважимо, що деформування вкладиша за товщиною також відбувається нелінійно. Для більш точного моделювання нелінійного характеру взаємодії вала та вкладиша можна вдатися до подрібнення скінченних елементів. Але у цьому випадку збільшиться кількість невідомих у системі рівнянь МСЕ, що у підсумку значно вплине на ефективність обчислень.

Альтернативою збільшенню кількості елементів може бути введення пружної основи, жорсткість якої $є$ деякою параболічною фрункцією за довжиною. В такому випадку, адекватного опису реакції пружної основи можна досягти, застосувавши значно меншу кількість елементів. Метою даної статі $€$ розробка скінченного елементу з параболічною апроксимацією жорсткості пружної основи уздовж елементу, оскільки публікації стосовно матриць жорсткості стрижневого елементу з такими властивостями авторам на даний час невідомі.

Виведення матриці жорсткості скінченного елементу. Аналізуючи взаємодію вала з пружною основою, створюваною вкладишем підшипника, природним $є$ припустити, що реакція вкладиша на кутові переміщення перерізу вала та відповідні розтягуючі зусилля при деформації пружної основи відсутні. Внаслідок малого відношення товщини вкладиша до діаметру вала знехтуємо також деформаціями зсуву у матеріалі вкладиша. Як результат, приходимо до моделі пружної основи Вінклера [4], яка зарекомендувала себе у розрахунках деформування металевих підшипників [5]. Згідно гіпотезі Вінклера реакція пружної основи $R(x)$ діє перпендикулярно до осі валах, $€$ пропорційною поперечним переміщенням $\Delta y(x)$ і $\Delta z(x)$ та не залежить від стану сусідніх перерізів. 
Нижче будемо розглядати лише площину $x O y$, але усі викладки для площини $x O z \in$ аналогічними. Таким чином, вираз для реакції пружної основи має вигляд

$$
R(x)=k(x) \cdot \Delta y(x),
$$

де $x$ - поздовжня координата скінченного елемента; $\Delta y$-поперечне переміщення скінченного елемента; $k(x)$ - функція коефіцієнта жорсткості пружної основи, що далі визначається як

$$
k(x)=\alpha+\frac{\beta \cdot x}{L}+4 \frac{\gamma \cdot x(L-x)}{L^{2}} .
$$

Тут $L$ - довжина скінченного елемента; $\alpha, \beta, \gamma$ - коефіцієнти, що характеризують властивості пружної основи. Геометричний зміст цих коефіцієнтів проілюстровано на рис. 1.

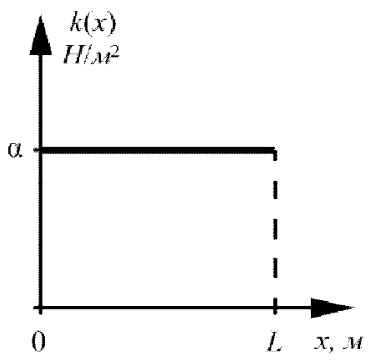

a)

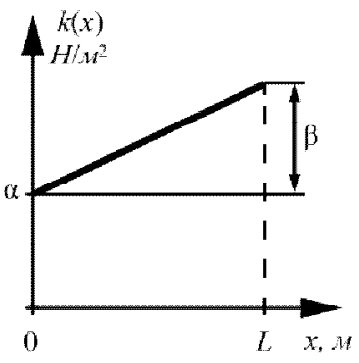

б)

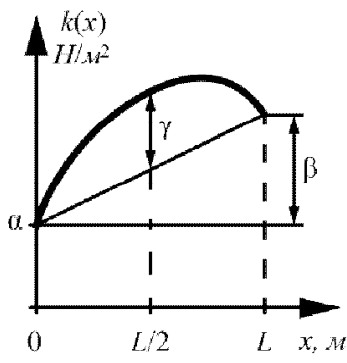

B)

Рис. 1 - Коефіцієнт жорсткості пружної основи:

а) постійна жорсткість, б) лінійна жорсткість, в) параболічна жорсткість

На практиці коефріцієнти у фрормулі (3) можна визначити за формулами:

$$
\begin{gathered}
\alpha=\frac{R(0)}{\Delta y(0)}, \\
\beta=\frac{R(L)}{\Delta y(L)}-\alpha, \\
\gamma=\frac{R(L / 2)}{\Delta y(L / 2)}-\left(\alpha+\frac{\beta}{2}\right) .
\end{gathered}
$$

Значення $\alpha$ повинно бути додатнім, а значення $\beta$ i $\gamma$ можуть бути як додатними так і від'ємними, але їх значення повинні бути такими, щоб значення функції $k(x)$ по всій довжині елемента не було від'ємним. 
Положення елемента визначається чотирма переміщеннями: двома лінійними переміщеннями вузлів на кінцях елемента вздовж осі $y$ та двома кутовими переміщення вузлів відносно осі $z$. Таким чином, закон змінення прогину скінченного елемента можна апроксимувати поліномом третього степеня [16]

$$
y(x)=a_{1}+a_{2} x+a_{3} x^{2}+a_{4} x^{3},
$$

де $a_{1}, a_{2}, a_{3}, a_{4}$ - довільні змінні, що залежать від вузлових переміщень.

Якщо має місце умова нерозривності скінченного елемента (вала) та пружної основи (вкладиша підшипника), то повинна виконуватись умова рівності прогинів скінченного елемента та пружної основи:

$$
y(x)=\Delta y(x) .
$$

Вираз для прогину скінченного елемента (7) у матричній фрормі матиме вигляд

$$
y(x)=\{X\}\{a\},
$$

де $\{X\}$ - вектор-рядок апроксимуючого полінома:

$$
\{X\}=\left\{\begin{array}{llll}
1 & x & x^{2} & x^{3}
\end{array}\right\}
$$

$\{a\}$ - вектор-стовпець незалежних коефіцієнтів:

$$
\{a\}=\left\{\begin{array}{llll}
a_{1} & a_{2} & a_{3} & a_{4}
\end{array}\right\}^{T} .
$$

Вектор вузлових переміщень визначається виразом

$$
\{q\}=[H]\{a\} .
$$

Матриця $[H]$ отримана з граничних умов форми згину скінченного елемента (7) на кінцях: два перших рядки відповідають умовам на кінці 3 координатою $x=0$, а два останні - з координатою $x=L$. Матриця має вигляд [1]

$$
[H]=\left[\begin{array}{cccc}
1 & 0 & 0 & 0 \\
0 & 1 & 0 & 0 \\
1 & L & L^{2} & L^{3} \\
0 & 1 & 2 L & 3 L^{2}
\end{array}\right] .
$$

Якщо ввести вектор одиничних вузлових переміщень $\left\{q_{1}\right\}$ і визначити незалежні коефіцієнти $\{a\}$ у формулі (10), то можна отримати

$$
\{a\}=[H]^{-1}\left\{q_{1}\right\} \text {. }
$$


Реакція пружної основи (2) у матричній формі з урахуванням (8), (9) та (11) може бути представлена у вигляді

$$
R(x)=k(x)\{X\}[H]^{-1}\left\{q_{1}\right\} .
$$

Робота пружної основи на одиничних переміщеннях визначається за формулою

$$
A=\frac{1}{2} \int_{0}^{L} R^{T}(x) \Delta y(x) d x
$$

підставивши в яку (8), (9), (11) та (12), отримаємо

$$
A=\frac{1}{2} \int_{0}^{L} k(x)\left(\{X\}[H]^{-1}\left\{q_{1}\right\}\right)^{T}\{X\}[H]^{-1}\left\{q_{1}\right\} d x .
$$

Після відповідних перетворень вираз для роботи набуває вигляд

$$
A=\frac{1}{2}\left\{q_{1}\right\}^{T} \int_{0}^{L} k(x)\left([H]^{-1}\right)^{T}\{X\}^{T}\{X\}[H]^{-1} d x\left\{q_{1}\right\} .
$$

Формулу для роботи пружної основи на одиничних переміщеннях можна також записати так

$$
A=\frac{1}{2}\left\{q_{1}\right\}^{T}\left[K_{n o}\right]\left\{q_{1}\right\},
$$

де вираз для матриці жорсткості має вигляд

$$
\left[K_{n o}\right]=\int_{0}^{L} k(x)\left([H]^{-1}\right)^{T}\{X\}^{T}\{X\}[H]^{-1} d x .
$$

Виконавши перетворення, отримаємо остаточний вираз для шуканої матриці жорсткості скінченного елемента у вигляді суми трьох матриць:

$$
\begin{gathered}
{\left[K_{n o}\right] \equiv\left[K_{\alpha \beta \gamma}\right]=\left[K_{\alpha}\right]+\left[K_{\beta}\right]+\left[K_{\gamma}\right],} \\
{\left[K_{\alpha}\right]=\frac{L \cdot \alpha}{420}\left[\begin{array}{cccc}
156 & 22 L & 54 & -13 L \\
22 L & 4 L^{2} & 13 L & -3 L^{2} \\
54 & 13 L & 156 & -22 L \\
-13 L & -3 L^{2} & -22 L & 4 L^{2}
\end{array}\right],}
\end{gathered}
$$




$$
\begin{gathered}
{\left[K_{\beta}\right]=\frac{L \cdot \beta}{840}\left[\begin{array}{cccc}
72 & 14 L & 54 & -12 L \\
14 L & 3 L^{2} & 14 L & -3 L^{2} \\
54 & 14 L & 240 & -30 L \\
-12 L & -3 L^{2} & -30 L & 5 L^{2}
\end{array}\right],} \\
{\left[K_{\gamma}\right]=\frac{L \cdot \gamma}{630}\left[\begin{array}{cccc}
140 & 25 L & 70 & -17 L \\
25 L & 5 L^{2} & 17 L & -4 L^{2} \\
70 & 17 L & 140 & -25 L \\
-17 L & -4 L^{2} & -25 L & 5 L^{2}
\end{array}\right] .}
\end{gathered}
$$

Перша складова матриці жорсткості (14) відповідає постійній жорсткості вздовж елемента та збігається з аналогічними, що наведені у [1, 2, 17]. Вона відповідає коефіцієнту жорсткості на рис. 1,а. Друга складова (15) - лінійно-змінній жорсткості (рис. 1,б), при цьому коефріцієнт жорсткості $k(0)$ буде дорівнювати нулю. Третя складова (16) - параболічнозмінній жорсткості (рис. 1,8) з нульовими значеннями коефіцієнта жорсткості на кінцях: $k(0)=k(L)=0$.

Окремим випадком, при використанні тільки перших двох доданків у формулі (13), є матриця жорсткості з довільним лінійним розподілом жорсткості пружної основи, яка може бути представлена як

$$
\left[K_{\alpha \beta}\right]=\left[K_{\alpha}\right]+\left[K_{\beta}\right] .
$$

\section{Порівняння скінченних елементів з різним представленням} жорсткості пружної основи. Для порівняння скінченних елементів 3 постійним, лінійним та параболічним розподілом жорсткості вздовж елемента були виконані систематичні розрахунки. У якості об'єкта дослідження була обрана балка, яка $є$ типовим розрахунковим випадком ізольованого підшипника валопровода. Умовна схема балки з діючими на неї силами і моментами зображена на рис. 2. Довжина балки дорівнює $1 \mathcal{M}$, поперечний переріз має форму круга діаметром $0,5 \mathrm{M}$, матеріалом балки $є$ конструкційна сталь з модулем Юнга $2 \cdot 10^{5}$ МПа, та коефіцієнтом Пуассона 0,3.

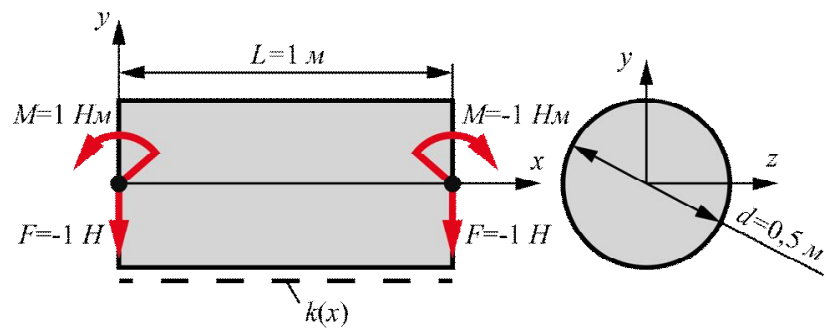

Рис. 2 - Розрахункова схема балки 
Єдиною опорою балки є пружна основа вздовж усієї балки. Оскільки визначення змінної жорсткості вкладиша є предметом окремого дослідження, фуннкцію коефріцієнта жорсткості умовно задано кубічним поліномом

$$
k(x)=\left(2-2,5 \cdot x+15 \cdot(x-0,5)^{2}-5 \cdot(x-0,25)^{3}\right) \cdot 10^{11}, H / \mathrm{M}^{2},
$$

при цьому відриву вала від основи не буде.

На рис. 3 зображено різні апроксимації функції (18).

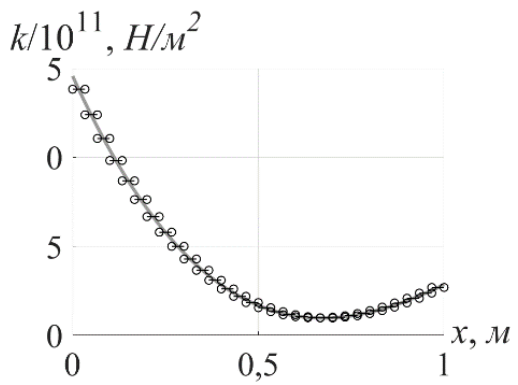

a)

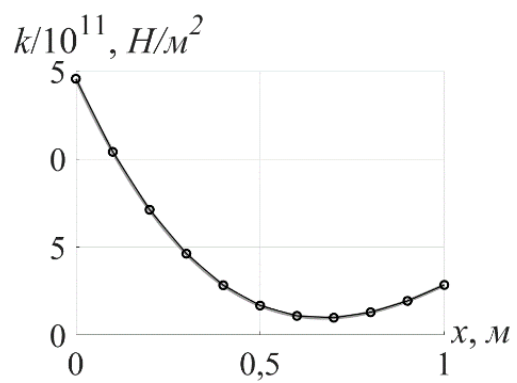

б)

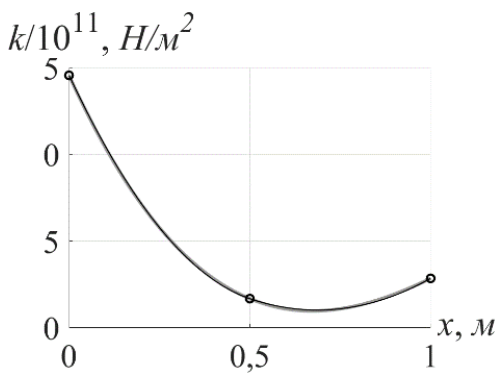

B)

Рис. 3 - Функція жорсткості вздовж елемента:

а) постійний коефіцієнт жорсткості (30 ділянок);

б) лінійний коефіцієнт жорсткості (10 ділянок);

в) параболічний коефіцієнт жорсткості (2 ділянки)

У першому випадку (рис. 3,a) функцію апроксимовано 30-ма ділянками з постійною жорсткістю, але коефіцієнт $\alpha$, на відміну від фрормули (4), визначався так

$$
\alpha=\left(\frac{R(0)}{\Delta y(0)}+\frac{R(L)}{\Delta y(L)}\right) / 2 .
$$

У другому випадку (рис. 3,6) апроксимація була здійснена кусковолінійно на 10-ти ділянках. Видно, що дана апроксимація набагато краще описує фрункцію жорсткості за меншої кількості елементів ніж у поперед214 
ньому випадку. У третьому випадку (рис. 3,в) застосовано параболічну апроксимацію усього на двох ділянках. Отже, в останньому випадку та ж сама точність апроксимації досягнута за кількості ділянок у п'ять разів менше ніж у випадку лінійного розподілу жорсткості та у 15 разів менше ніж у випадку постійної жорсткості.

Відповідно до цього були проведені розрахунки з різною кількістю скінченних елементів уздовж балки з використанням різних матриць жорсткості пружної основи (13), (14) та (17). У якості матриці жорсткості самої балки $\left[K_{c e}\right]$ була використана матриця жорсткості скінченного елемента балки Тимошенка, тобто з урахуванням деформацій зсуву [7].

На рис. 4 представлені графріки величини прогину балки у трьох перерізах: з координатами $x=0, x=L / 2$ та $x=L$.

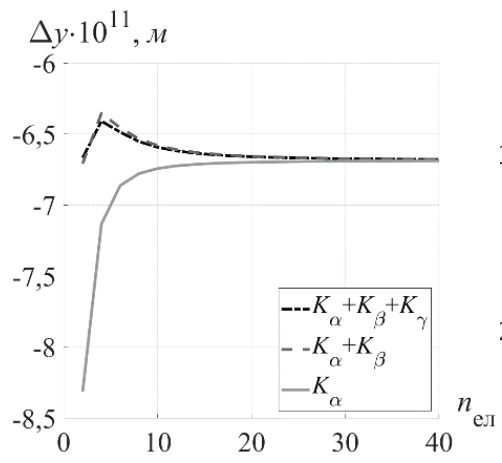

a)

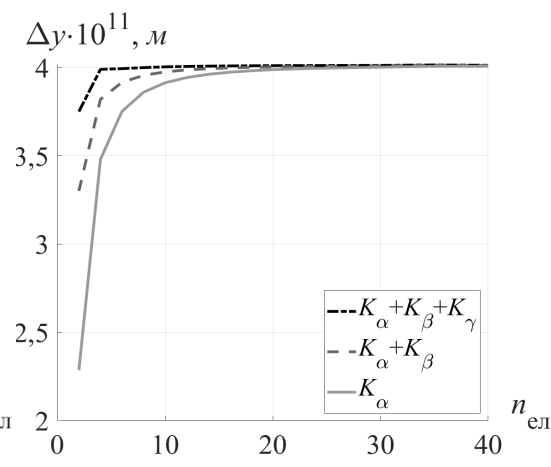

б)

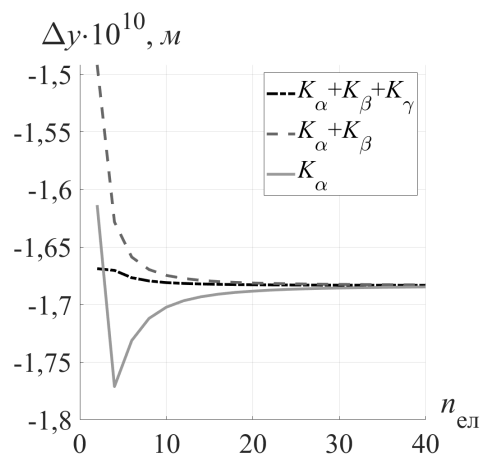

B)

Рис. 4 - Переміщення у перерізах балки:

а) переріз $x=0$; б) переріз $x=L / 2$; в) переріз $x=L$

Як видно з графріків, для всіх перерізів балки збільшення кількості скінченних елементів, як це і очікувалось, призводить до зменшення різниці між результатами застосування трьох різних матриць жорсткості 
пружної основи, і при кількості елементів більше 30-ти ця різниця складає не більше $0,5 \%$.

За невеликої кількості елементів використання матриці (14) та (17) призводить до великої похибки. Використання ж матриці з параболічною апроксимацією жорсткості (13) у цьому випадку дає більш близькі до точного значення прогинів вала результати. При використанні лише двох елементів на підшипник матриця жорсткості з постійною жорсткістю дає похибку прогинів у 42\%, з лінійною жорсткістю - у $18 \%$, а з параболічною - не більше 7\%.

На основі графіків збіжності прогинів можна дати рекомендації щодо мінімально необхідної кількості скінченних елементів для моделювання одного підшипника з відношенням довжини вкладиша до діаметра вала 2:1. При використанні матриці $\left[K_{\alpha}\right]$ ця кількість складає 30 елементів, для матриці $\left[K_{\alpha \beta}\right]-20$, а для матриці з параболічною апроксимацією $\left[K_{\alpha \beta \gamma}\right]$ достатньо лише 12 скінченних елементів.

Виконаний аналіз свідчить про доцільність використання скінченних елементів на пружній основі з параболічним законом зміни жорсткості за довжиною скінченного елемента у якості моделі вкладиша підшипника у розрахунках згину суднового валопровода.

Висновки. Розроблено матрицю жорсткості пружної основи з параболічним законом зміни коефіцієнта жорсткості за довжиною. Ця матриця більш точно моделює конструкції зі змінними уздовж умовами спирання на пружні опори, наприклад, підшипники судового валопроводу з неметалевими вкладишами. При використанні розробленої матриці достатньо використовувати 12 скінченних елементів для одного підшипника, у той час, коли при використанні традиційної матриці [2] необхідно більш ніж у два рази більше елементів для досягнення прийнятної точності. Це є принципово важливим для підвищення ефективності розрахунків згину суднового валопровода у задачах проектування технології центрування валопровода та аналізу роторних коливань.

Ефективність застосування нової матриці жорсткості стрижневого скінченного елемента на пружній основі має бути також підтверджена ітеративними розрахунками згину реальних валопроводів, з використанням алгоритму, який зараз розробляється.

\section{БІБЛІОГРАФІЧНІ ПОСИЛАННЯ}

1. Веселов В. Н. Построение матрицы жёсткости рельсового пути башенного крана методом конечных элементов. // Вестник АГТУ. Астрахань. 2006 . №1 (30). С. 203-206.

2. Козляков В. В., Финкель Г. В., Хархурим И. Я. Проектирование доковых опорных устройств. Л.: Судостроение, 1973. 76 с.

3. Колосова Г. С., Куроедов В. В.Применение функций Крылова А. Н. для решения задач строительной механики // Строительство уникальных зданий и сооружений, 2013. №4 (9). С. 42-52.

4. Крылов А. Н. О расчёте балок на упругом основании. Издание второе. Л.: Издательство академии наук СССР, 1931. 154 с. 
5. Кузьменко А. Г. Метод алгебраических уравнений в контактной механике. Хмельницкий: ХНУ, 2006. 448 с.

6. Постнов В. А., Хархурим И. Я. Метод конечных элементов в расчётах судовых конструкций. Л: Судостроение, 1974. 344 с.

7. ANSYS Theoretical manual

8. Chen J., Feng Y., Shu W. An Improved Solution for Beam on Elastic Foundation using Quintic Displacement Functions // KSCE Journal of Civil Engineering. - Korean Society of Civil Engineers, 2015. P.1-11.

9. Chen S. F. Stiffness matrix for beams on elastic foundation by virtual work principle // Soils and Foundations. The Japanese Geotechnical Society. 1972. P. 46-56.

10. Eisenberger M., Yankelevsky D. Z. Exact stiffness matrix for beams on elastic foundation // Computers \& Structures. Oxford: Pergamon Press Ltd. 1985. Vol. 21. No 6. P. $1355-1359$.

11. Janco R. Solution Methods for Beam and Frames on Elastic Foundation Using the Finite Element Method // Mechanical Structures and Foundation Engineering 2010. Proceedings of International scientific conference MSFE 2010. - Ostrava, 2010.

12. Mourelatost Z. P., Parsons M. G. A finite element analysis of beams on elastic foundation including shear and axial effects // Computers \& Structures. Oxford: Pergamon Press Ltd. 1987. Vol 27. No 3. P. 323-331.

13. Murawski L. Static and dynamic analyses on marine propulsion systems. Warszawa: Oficyna Wydawnicza Politechniki Warszawskiej, 2003. 99 p.

14. Requirements concerning. Machinery installations. M52 IACS, 2016. 241 p.

15. Use of seawater lubricated tube bearings to eliminate stern tube oil pollution from ships. IMO, 2008. 6 p.

16. Yankelevsky D. Z., Eisenberger M. An exact finite element for beams on elastic foundation // Proceedings of the Eleventh International Conference on Soil Mechanics and Foundation Engineering. San Francisco, 1985.

17. Zhaohua F., Cook R. D. Beam elements on two-parameter elastic foundations // Journal of Engineering Mechanics. ASCE. 1983. Vol. 109. No 6.,

Удк:624.04, 629.5.015.4, 629.5.035.8

\section{${ }^{1}$ А. И. Урсолов, канд. техн. наук, ${ }^{2}$ Ю. А. Батрак \\ МАТРИЦА ЖЕСТКОСТИ СТЕРЖНЕВОГО КОНЕЧНОГО ЭЛЕМЕНТА НА УПРУГОМ ОСНОВАНИИ С НЕЛІНІЙНОЙ ЖЕСТКОСТЬЮ ВДОЛЬ ЭЛЕМЕНТА}

Рассмотрена задача моделирования подшипника судового валопровода с неметаллическим вкладышем как упругого основания методом конечных элементов. Выполнен анализ существующих матриц жёсткости стержневых конечных элементов на упругом основании. Разработана матрица жёсткости элемента на упругом основании Винклеровского типа с параболическим законом изменения коэффициента жёсткости по длине элемента. Показана эффективность разработанной матрицы жёсткости по сравнению с матрицами, полученными с применением постоянного и линейного законов изменения жёсткости. Даны рекомендации по выбору количества элементов, необходимых для адекватного моделирования неметаллических вкладышей подшипников судового валопровода.

Ключевые слова: подшипник, упругое основание, метод конечных элементов, матрица жёсткости, стержневой конечный элемент 


\section{${ }^{1}$ A. I. Ursolov, PhD (Tech.), ${ }^{2}$ Y. A. Batrak \\ STIFFNESS MATRIX OF THE BEAM FINITE ELEMENT ON ELASTIC FOUNDATION WITH NON-LINEAR STIFFNESS ALONG THE ELEMENT}

The modelling of marine propulsion shafting bearing with non-metallic liner as an elastic foundation using the finite element method is considered. The stiffness matrices of existing beam finite elements on the elastic foundation are analyzed. The element stiffness matrix on the Winkler elastic foundation with the parabolic distribution of stiffness coefficient along the element is developed. The efficiency of the developed stiffness matrix compared to matrices with constant and linear stiffness coefficient distributions is shown. The recommendations on choosing element number required for adequate modelling of the non-metallic liners of the marine propulsion shafting bearings are given.

Keywords: bearing, elastic foundation, finite element method, stiffness matrix, beam finite element

The main problem in the shaft bending calculation is boundary conditions at the bearings, especially at aftermost stern tube bearing that has nonmetallic liner. The main purpose of the article is to provide a base for the marine propulsion shafting bending calculation using an elastic foundation approach to the bearing modelling. The stiffness of such an elastic foundation could be highly variable along the bearing.

Several stiffness matrices of the elastic foundation used in the finite element method are known $[1-3,8-10,12,16,17]$. However, there is no stiffness matrix having variable stiffness with non-linear law along the element.

The authors developed a new stiffness matrix having parabolic law of stiffness function

$$
k(x)=\alpha+\frac{\beta \cdot x}{L}+4 \frac{\gamma \cdot x(L-x)}{L^{2}},
$$

where $L$ is length of the element, $\mathrm{m} ; \alpha, \beta, \gamma$-coefficients determining properties of the elastic foundation (Fig. 1).

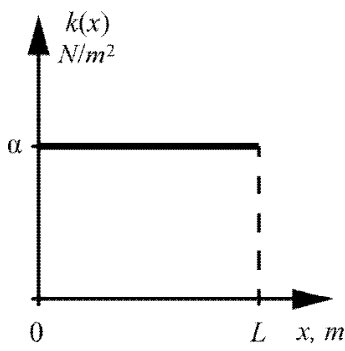

a)

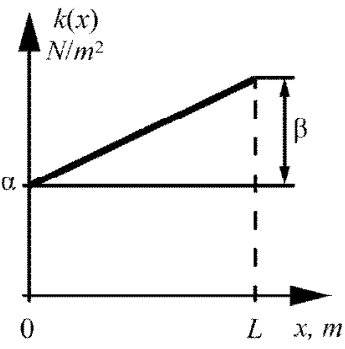

b)

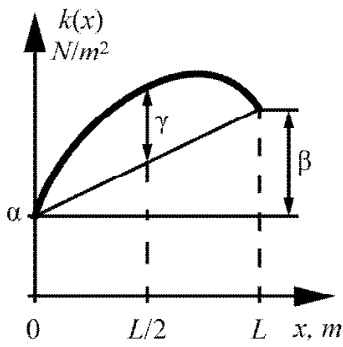

c)

Fig. 1 - Stiffness coefficient of the elastic foundation:

a) constant, b) linear, c) parabolic 
Potential energy of the elastic foundation deformation has been derived in the form

$$
A=0,5\{q\}^{T}\left[K_{\alpha \beta \gamma}\right]\{q\},
$$

where $\{q\}$ is the vector of nodal displacements, $\left[K_{\alpha \beta \gamma}\right]$ is the developed stiffness matrix:

$$
\begin{gathered}
{\left[K_{\alpha \beta \gamma}\right]=\left[K_{\alpha}\right]+\left[K_{\beta}\right]+\left[K_{\gamma}\right],} \\
{\left[K_{\alpha}\right]=\frac{L \cdot \alpha}{420}\left[\begin{array}{cccc}
156 & 22 L & 54 & -13 L \\
22 L & 4 L^{2} & 13 L & -3 L^{2} \\
54 & 13 L & 156 & -22 L \\
-13 L & -3 L^{2} & -22 L & 4 L^{2}
\end{array}\right],} \\
{\left[K_{\beta}\right]=\frac{L^{2} \cdot \beta}{840}\left[\begin{array}{cccc}
72 & 14 L & 54 & -12 L \\
14 L & 3 L^{2} & 14 L & -3 L^{2} \\
54 & 14 L & 240 & -30 L \\
-12 L & -3 L^{2} & -30 L & 5 L^{2}
\end{array}\right],} \\
{\left[K_{\gamma}\right]=\frac{L \cdot \gamma}{630}\left[\begin{array}{cccc}
140 & 25 L & 70 & -17 L \\
25 L & 5 L^{2} & 17 L & -4 L^{2} \\
70 & 17 L & 140 & -25 L \\
-17 L & -4 L^{2} & -25 L & 5 L^{2}
\end{array}\right] .}
\end{gathered}
$$

The comparison of the stiffness matrices with constant, linear and parabolic stiffness distribution is performed using typical marine propulsion bearing as an example. For accurate modelling, it is needed to use 30 elements per bearing using the constant stiffness matrix, 20 elements using linear stiffness matrix and 12 using parabolic stiffness matrix. It shows the efficiency of the developed matrix in reducing computational time when multiple calculations are required in the iterative procedures.

\section{REFERENCES}

1. Beselov V. N. Stiffness matrix derivation for a rail track of a tower crane using the finite element method // Bulletin of Astrakhan State Technical University. Astrakhan. 2006. No 1 (30). P. 203-206. (in Russian).

2. Kozlyakov V. V., Finkel G. V., Harhurim I. Y. Designing dock support devices. Leningrad: Shipbuilding, 1973. 176 p. (in Russian).

3. Kolosova G. S., Kuroedov V. V. Application of the Krylov functions to solving structural mechanics tasks // Construction of the unique buildings and structures. 2013. No 4 (9). P. 42-52. (in Russian). 
4. Krylov A. N. About calculations of the beams on elastic foundation. Second edition. Leningrad: Publisher Academy of Sciences of the USSR, 1931. 154 p. (in Russian).

5. Kuzmenko A. G. The method of algebraic equations in contact mechanics. Khmelnitsky: KhNU. 2006. 448 p. (in Russian).

6. Postnov V. A., Harhurim I. Y. The finite element method in ship constructions calculations. Leningrad: Shipbuilding, 1974. - 344 p. (in Russian).

7. ANSYS Theoretical manual.

8. Chen J., Feng Y., Shu W. An Improved Solution for Beam on Elastic Foundation using Quintic Displacement Functions // KSCE Journal of Civil Engineering. Korean Society of Civil Engineers. 2015. P. 1-11.

9. Chen S. F. Stiffness matrix for beams on elastic foundation by virtual work principle // Soils and Foundations. The Japanese Geotechnical Society. 1972. P. 46-56.

10. Eisenberger M., Yankelevsky D. Z. Exact stiffness matrix for beams on elastic foundation // Computers \& Structures. Oxford: Pergamon Press Ltd. 1985. Vol. 21, No 6. P. $1355-1359$.

11. Janco R. Solution Methods for Beam and Frames on Elastic Foundation Using the Finite Element Method // Mechanical Structures and Foundation Engineering 2010. Proceedings of International scientific conference MSFE 2010. - Ostrava, 2010.

12. Mourelatost Z. P., Parsons M. G. A finite element analysis of beams on elastic foundation including shear and axial effects // Computers \& Structures. Oxford: Pergamon Press Ltd. 1987. Vol. 27. No 3. P. 323-331.

13. Murawski L. Static and dynamic analyses on marine propulsion systems. Warszawa: Oficyna Wydawnicza Politechniki Warszawskiej, 2003. 99 p.

14. Requirements concerning. Machinery installations. M52 IACS, 2016. 241 p.

15. Use of seawater lubricated tube bearings to eliminate stern tube oil pollution from ships. IMO, 2008. 6 p.

16. Yankelevsky D. Z., Eisenberger M. An exact finite element for beams on elastic foundation // Proceedings of the Eleventh International Conference on Soil Mechanics and Foundation Engineering. San Francisco, 1985.

17. Zhaohua F., Cook R. D. Beam elements on two-parameter elastic foundations // Journal of Engineering Mechanics. ASCE. 1983. Vol. 109. No 6.

${ }^{1}$ Національний університет кораблебудування

ім. адм. Макарова,

${ }^{2}$ ПП «Інтелектуальні морські технології»

Миколаїв, Україна

14.02.2019 